\title{
Efektyvaus alerginio rinito gydymo svarba
}

\author{
Laura Tamašauskienė, Brigita Šitkauskienè \\ LSMU MA Pulmonologijos ir imunologijos klinika
}

\begin{abstract}
Alerginiu rinitu serga apie 30 proc. visos populiacijos [1]. Ši liga blogina gyvenimo kokybę bei mažina darbo ir mokymosi produktyvumą. Be to, dauguma žmonių, sergančiu alerginiu rinitu, serga ir astma. Apskaičiuota, kad 60-70 proc. žmonių, kuriems diagnozuota astma, serga alerginiu rinitu $[2,3,4]$. Šiems pacientams būdingesnè sunki astmos eiga bei dažni šios ligos paūmèjimai. Tyrimai rodo, kad efektyvus rinito gydymas gali padèti kontroliuoti astmos simptomus [5, 6]. Šio straipsnio tikslas apžvelgti alerginio rinito diagnostikos ir gydymo metodus bei šios ligos svarbą astmos išsivystymui bei eigai.
\end{abstract}

\section{ALERGINIO RINITO KLASIFIKACIJA IR DIAGNOSTIKA}

Alerginio rinito klinikinius požymius lemia imuninès reakcijos (dažniausiai susijusios su imunoglobulinu (Ig) E), kilusios po nosies gleivinès sąlyčio su alergenu. Dažniausi šios ligos simptomai yra rinorèja, nosies užsikimšimas, niežulys, čiaudulys. Dažnai kartu pasireiškia ir alerginis konjunktyvitas. EHealthMe tyrimo duomenimis, iš 2896 sergančių alerginiu rinitu, sunkumu kvėpuoti skundèsi 150, gydymo antidepresantais prireikè 1330 pacientų, susierzinimą, ittampą jaute 119 pacientų, galvos skausmą - 116, svaiguli - 115 , nuovargi - 114, šleikštuli, pykinimą 108 , skausmą - 104, minčių nusižudyti kilo 115 tiriamųjų [7]. Pagal simptomuc trukmę alerginis rinitas klasifikuojamas i epizodini ir nuolatini, o pagal sunkumą - i lengvos eigos, vidutinès ir sunkios eigos (1 lentelè) [5].

Diagnozuojant alerginị rinitą (pagal ARIA (angl. Allergic rhinitis and its impact on asthma) rekomendacijas) rekomenduojama pradèti nuo specialaus klausimyno pildymo (2 lentelè) [5]. Jis padeda sukonkretinti ir susisteminti paciento nusiskundimus. Pirmoje klausimyno dalyje išvardyti alerginiam rinitui nebūdingi simptomai. Jei pacientas teigiamai atsakè bent i vieną šios dalies klausimą, vadinasi, reikètu ji tirti dèl kitu ligu (pvz., sinusito). Jei pacientas skundžiasi nosies "tekèjimu“ ir dar bent vienu antroje dalyje išvardytu simptomu, didelè tikimybè, kad jis serga alerginiu rinitu, todèl turi būti siunčiamas tirti toliau. Tačiau, jei pacientas nenurodo kitu požymių, tik nosies „tekejimą“, alerginio rinito tikimybė yra mažesnè. Jei pažymimi visi antroje dalyje išvardyti simptomai, išskyrus nosies „tekèjimą“, alerginio rinito diagnozè mažai tikètina.

Jei, įvertinus klausimyno rezultatus, alerginio rinito diagnozè yra tikètina, būtina pacientą toliau tirti ir patikslinti diagnozę. Pradedama nuo objektyvios apžiūros, kurios metu galima pastebèti skersinę nosies raukšlę, ratilus paakiuose. Kitoms ligoms atmesti gali būti atliekama priekine rinoskopija ir nosies endoskopija. Šiais tyrimais nustatomos ir kitos galimos rinito priežastys (pvz.: anatominès anomalijos) ar alerginio rinito sukeltos komplikacijos (pvz., polipai). Organizmo įsijautrinimui įvairiems alergenams patvirtinti yra atliekami odos dūrio méginiai ir specifinių IgE nustatymas kraujo serume. Jei reikia nustatyti konkretaus alergeno dozę, kuri sukelia alergijos simptomus, atliekamas nosies provokacinis tyrimas. Tai itin aktualu diagnozuojant profesines ligas.

\section{ALERGINIO RINITO GYDYMAS}

Svarbiausi alerginio rinito gydymo tikslai - pagerinti miego kokybę užtikrinant normalų miegą, normalų aktyvumą dieną (darbo ir mokyklos lankymas, sportas, laisvalaikis), sumažinant simptomų dažnumą ir stiprumą gydant vaistais, kurie nesukeltu nepageidaujamų reiškinių. Nekontroliuojamas alerginis rinitas gali sukelti ar pasunkinti astmą, atopini dermatitą, rinosinusitą, nosies polipozę, otitą, apnèją, dantų problemas, gomurio anomalijas, migreną [8-10].
1 lentelè. Alerginio rinito klasifikacija $[5,11]$

\begin{tabular}{|c|c|}
\hline Epizodinis & Nuolatinis \\
\hline $\begin{array}{l}\text { Simptomai }<4 \\
\text { dienas per savaitę; } \\
\text { arba }<4 \text { savaites. }\end{array}$ & $\begin{array}{l}\text { Simptomai }>4 \\
\text { dienas per savaitę; } \\
\text { arba }>4 \text { savaites. }\end{array}$ \\
\hline Lengvas & Vidutinis/sunkus \\
\hline $\begin{array}{l}\text { Visi išvardyti: } \\
\text { - } \quad \text { normalus miegas; } \\
\text { - } \\
\text { nesutrikusi kasdienè } \\
\text { veikla, sportas, } \\
\text { laisvalaikis; } \\
\text { - } \quad \text { nesutrikęs darbo ir } \\
\text { mokyklos lankymas; } \\
\text { simptomai yra, bet } \\
\text { ne varginantys. }\end{array}$ & $\begin{array}{ll}\text { - } & \text { miego sutrikdymas; } \\
\text { kasdienės } \\
\text { veiklos, sporto, } \\
\text { laisvalaikio } \\
\text { sutrikdymas; } \\
\text { darbo ir moky- } \\
\text { klos lankymo } \\
\text { sutrikdymas; } \\
\text { varginantys } \\
\text { simptomai. }\end{array}$ \\
\hline
\end{tabular}

2 lentelè. Alerginio rinito klausimynas

Klausimas

1. Ar skundžiatès bent vienu išvardytu simptomu?

- Simptomai vienoje nosies puseje

- Tirštos, žalios ar geltonos išskyros iš nosies

- Sekreto nutekèjimas iš nosies iz gerklę

Veido skausmas

- Pasikartojantis kraujavimas iš nosies

- Uoslès sutrikimas

2. Ar skundžiatès bent vienu iš išvardytų simptomų bent 1 valandą per dieną?

- Nosies „tekejjimas“

- Čiaudulys

- Nosies užsikimšimas

- Nosies niežulys

- Konjunktyvitas (raudonos, niežtinčios akys)

Pagal ARIA rekomendacijas, pradedant gydyti alergini rinitą, svarbu vengti alergenų, kurie provokuoja simptomus $[5,11]$. Vaistu pasirinkimas priklauso nuo ligos klinikinių požymių sunkumo ir trukmès. Pagrindinis medikamentinio gydymo tikslas - parinkti vaistus, reguliuojančius alergeno sukelto imuninio atsako pakitimus (veikiančius ligos patogenezę) bei leidžiančius pasiekti ir užtikrinti ligos kontrolę. Jei alerginio rinito simptomai yra epizodiniai ir lengvos eigos, skiriama II kartos geriamųju ar vietinio poveikio antihistamininių vaistų. Dekongestantai gali būti skiriami tik trumpą laiką (<7d.) kaip pagalbinè priemonè mažinant nosies obstrukciją, nes ilgalaikis jų vartojimas gali tapti medikamentinès alergijos priežastimi. Jei alerginio rinito 
3 lentelè. Vaistų poveikis alerginio rinito simptomams [12]

\begin{tabular}{|c|c|c|c|c|c|c|c|}
\hline & & & & \multicolumn{4}{|c|}{ Pirmos eilès vaistai } \\
\hline Simptomai & $\begin{array}{l}\text { Anticho- } \\
\text { linerginiai } \\
\text { vaistai }\end{array}$ & $\begin{array}{l}\text { Dekonges- } \\
\text { tantai }\end{array}$ & $\begin{array}{l}\text { Putliụjų } \\
\text { ląstelių } \\
\text { stabiliza- } \\
\text { toriai }\end{array}$ & $\begin{array}{l}\text { Leukotrie- } \\
\text { nų antago- } \\
\text { nistai }\end{array}$ & $\begin{array}{l}\text { Geriamie- } \\
\text { ji antihis- } \\
\text { tamininiai } \\
\text { vaistai }\end{array}$ & $\begin{array}{l}\text { Nosies } \\
\text { antihista- } \\
\text { mininiai } \\
\text { vaistai }\end{array}$ & $\begin{array}{l}\text { Nosies } \\
\text { gliko- } \\
\text { korti- } \\
\text { koidai }\end{array}$ \\
\hline $\begin{array}{l}\text { Nosies } \\
\text { užsikimšimas }\end{array}$ & - & + & $+/-$ & $+/-$ & $+/-$ & + & ++ \\
\hline $\begin{array}{l}\text { Nosies } \\
\text { niežulys }\end{array}$ & - & - & + & $+1-$ & + & + & + \\
\hline Rinorèja & + & - & + & + & + & + & ++ \\
\hline Čiaudulys & - & - & + & + & + & ++ & ++ \\
\hline $\begin{array}{l}\text { Akiǔ } \\
\text { niežulys }\end{array}$ & - & - & - & $+1-$ & + & ++ & + \\
\hline Ašarojimas & - & - & - & $+1-$ & + & ++ & + \\
\hline $\begin{array}{l}\text { Akiu } \\
\text { paraudimas }\end{array}$ & - & - & - & $+/-$ & + & ++ & + \\
\hline
\end{tabular}

simptomai yra epizodiniai ir vidutiniai/ sunkūs, rekomenduojama skirti tokius pat vaistus kaip esant lengvos eigos ligai ir svarstyti apie nosies gliukokortikoido skyrimą. Kiti antros eilès vaistai: antileukotrienai (pirmenybè sergantiems ir astma), kromonai. Šiuo metu kromonai, gydant alerginị rinitą, beveik nebeskiriami, nes jų terapinis poveikis dažnai nepakankamas, silpnesnis, lyginant su kitais vaistais (3 lentelè). Dažniausiai tokiais atvejais yra skiriami vietinio poveikio gliukokortikoidai. Jei alerginio rinito simptomai po 2-4 sav. sumažeja, tokị patị gydymą reikia tęsti dar 1 mèn., o jei efekto nèra - peržiūrèti diagnozę, ar laikomasi režimo, ar nèra infekcijos ir kitų priežasčių, rinktis kitą ar skirti papildomą vaistą. Esant nuolatiniam vidutinio sunkumo/ sunkiam alerginiam rinitui, pirmiausia skiriami nosies gliukokortikoidai (pirmos eilès vaistai). Kiti galimi pasirinktiniai vaistai - antihistamininiai, antileukotrienai. Jei po 2-4 sav. simptomai palengvėja, rekomenduojama gydymą pakeisti, renkantis vaistus iš žemesnès pakopos, ir tokị gydymą tęsti 1 mèn. Tačiau, jei simptomai lieka tokie patys, reikètuc dar kartą ịvertinti alerginio rinito diagnozę, atmesti kitas ligas. Jei alerginio rinito diagnozè patvirtinama, galima didinti nosies gliukokortikoidu dozę, esant niežuliui, čiauduliui pridèti antihistamininių vaistų, esant itin sunkiam nosies užsikimšimui - trumpą laiką dekongestantų. Jei ir šis gydymas neefektyvus, reikia spręsti dèl chirurginio gydymo galimybių.

Jei pacientas serga ir alerginiu konjunktyvitu, rekomenduojama skirti geriamuosius arba lašinamus $\mathfrak{i}$ akis antihistamininius vaistus. Nustačius, kad alerginio rinito simptomus sukelia vienas ar du vyraujantys alergenai, galima taikyti specifinę imunoterapiją (poodinę arba poliežuvinę). Taip organizmas palaipsniui "pripratinamas" prie alergeno, todèl sumažèja simptomų sunkumas ir dažnumas.

\section{Sèkmingo gydymo pagrindas - tinkamai pasirinktas vaistas}

Pagrindiniai vaistai alerginiam rinitui gydyti, kaip minèta, yra antihistamininių vaistų ir (ar) gliukokortikoidu purškalai.

Norint veiksmingai gydyti alergini rinitą, kai vargina nosies niežulys, čiaudulys, rekomenduojama skirti geriamuosius II kartos $\mathrm{H} 1$ antihistamininis vaistus. Dymista $^{\circ}$ vartojama simptominiam vidutinio sunkumo ir sunkiam sezoniniam ir nuolatiniam AR gydyti, kai monoterapija nosies antihistamininiais vaistiniais preparatais ar gliukokortikoidų purškalais nepakankamai veiksminga. Dymista ${ }^{\circ}$ nosies purškale yra azelastino hidrochlorido ir flutikazono propionato, kuriu veikimo mechanizmai skirtingi, todèl papildo ir sustiprina vienas kito poveiki slopinant alergini rinitą ir rinokonjunktyvito simptomus. Flutikazono propionatas - tai sintetinis gliukokortikoidas, o azelastinas priskiriamas prie stipriai ir ilgai veikiančių antihistamininių vaistinių preparatų, kuriam būdingos selektyvios H1 antagonistinès, putliąsias ląsteles stabilizuojančios ir uždegimą slopinančios savybès. In vivo ir in vitro tyrimu duomenys rodo, jog azelastinas slopina cheminių mediatorių, dalyvaujančių ankstyvosios ir vèlyvosios stadijos alerginėse reakcijose (leukotrienų, histamino, trombocitus aktyvinančio faktoriaus irserotonino), sintezę ar atsipalaidavimą.

\section{ALERGINIO RINITO IR ASTMOS SĄSAJOS}

Mokslo literatūra rodo, kad alerginis rinitas didina astmos riziką. Abi šios ligos išsivysto veikiant panašiems imu- niniams mechanizmams po sąlyčio su alergenu. Kanadoje atliktas tyrimas atskleidè, kad iš 107 pacientų, sergančių alerginiu rinitu, 26,1 proc. sirgo astma, o 39,1 proc. buvo nustatyta sutrikusi plaučiuc funkcija [4]. Mokslininkai teigia, kad, diagnozavus alerginị rinitą, reiketuc pagalvoti, ar pacientas neserga ir astma. Norint ivertinti astmos tikimybę, rekomenduojama užpildyti trumpą klausimyną [5]. Jei pacientas atsako teigiamai bent $\mathfrak{i}$ vieną klausimą, astmos tikimybė yra didelè, ir jis turi būti siunčiamas tirti toliau.

Tyrimas, kuriame buvo analizuojami vaikų, sergančių astma, plaučių funkcijos rodikliai ligos paūméjimo metu ir po jo, parode, kad pacientams, sergantiems alerginiu rinitu, plaučiu funkcija atsitaisè po ilgesnio laiko [2]. Naujuose mokslo darbuose pateikia duomenų, kad efektyvus alerginio rinito gydymas gali užkirsti kelią astmos išsivystymui, ypač specifinè imunoterapija $[3,6]$.

\section{APIBENDRINIMAS}

Alerginis rinitas yra labai dažna liga, kuri net tik blogina gyvenimo kokybę, bet ir didina astmos bei jos paūmẻjimų riziką. Dažniausi šios ligos simptomai yra rinorejja, nosies užsikimšimas, niežulys, čiaudulys. Dažnai kartu pasireiškia ir konjunktyvito požymių. Alerginio rinito diagnostika atliekama atsižvelgiant i paciento nusiskundimus, ligos anamnezę, juc vertinimui naudojant specialius klausimynus, atliekant odos dūrio mėginius ar/ir specifinių IgE kraujo serume tyrimą bei nosies provokacinị tyrimą, diferencinès diagnostikos tikslu atliekant rinoskopiją, nosies endoskopiją. Gydant šią ligą svarbu vengti alergeno, sukeliančio simptomus. Dažniausiai skiriami geriamieji arba nosies antihistamininiai preparatai, dekongestantai, i nosi purškiami gliukokortikoidai. Vaistu pasirinkimas priklauso nuo ligos simptomų dažnumo ir sunkumo. Jei nustatoma, kad alerginio rinito klinikinius požymius sukelia vienas ar du alergenai, taikoma specifinè imunoterapija. Laiku atlikta alerginio rinito diagnostika ir tinkamai parinktas gydymas ne tik sumažina ligos simptomus, bet leidžia pasiekti ligos kontrolę, pagerina gyvenimo kokybę ir sumažina astmos ir kitų susijusių ligu riziką, o jau sergant astma šios ligos paūmèjimų dažnumą. 